\title{
In vivo analysis of the helix-turn-helix motif of the fushi tarazu homeo domain of Drosophila melanogaster
}

\author{
Katsuo Furukubo-Tokunaga, ${ }^{1}$ Martin Müller, ${ }^{1,2}$ Markus Affolter, Leslie Pick, ${ }^{3}$ Urs Kloter, \\ and Walter J. Gehring \\ Department of Cell Biology, Biozentrum, University of Basel, $\mathrm{CH}-4056$ Basel, Switzerland
}

\begin{abstract}
We report a systematic mutational analysis of the helix-turn-helix motif (HTH) of the fushi tarazu (ftz) homeo domain (HD) of Drosophila. We started out by testing the function of chimeric $f t z$ proteins containing either a part of the Sex combs reduced (Scr) or the muscle segment homeobox (msh) HDs. By complementation tests in transgenic flies, cotransfection assays in cultured Drosophila cells and in vitro DNA-binding assays, we have found that the $f t z$ activity is retained in the ftz-Scr chimera but is lost in the ftz-msh chimera, which is defective in binding to an Antennapedia (Antp)-class target site. Further studies with a series of back-mutants of the ftz-msh chimera have revealed that a set of class-specific DNA backbone-contacting residues in the HTH, particularly Arg-28 and Arg-43, are required for efficient target site recognition and, hence, full $\mathrm{ftz}$ activity both in vitro and in vivo.
\end{abstract}

[Key Words: Homeo domain; helix-turn-helix motif; DNA-protein interaction; gene complementation]

Received February 13, 1992; revised version accepted April 9, 1992.

Many of the regulatory genes involved in the control of development share a common sequence element of 180 bp, the homeo box, which encodes a 60-amino-acid motif, the homeo domain $(\mathrm{HD}$; for review, see Scott et al. 1989; Gehring et al. 1990). The amino acid sequences of known HDs are conserved in evolution from yeast to higher vertebrates and plants (Shepherd et al. 1984; Scott et al. 1989; Ruberti et al. 1991). In vitro DNA-binding studies (Desplan et al. 1988; Hoey and Levine 1988; Müller et al. 1988) and structural studies (Qian et al. 1989; Kissinger et al. 1990; Otting et al. 1990; Wolberger et al. 1991) have revealed that HDs are sequence-specific DNA-binding domains that consist of three or four $\alpha$-helices separated by a loop and a turn. Two of the $\alpha$-helices, located in the carboxy-terminal portion of the HD, correspond to the helix-turn-helix (HTH) motif, which was initially identified in prokaryotic gene regulatory proteins as a sequence-specific recognition module (for reviews on HTH motifs, see Harrison and Aggarwal 1990; Steitz 1990).

On the basis of amino acid sequence similarities, HDs can be assigned to different classes (Scott et al. 1989). Although many of the HD proteins belonging to different classes share significant sequence similarity and are able to recognize similar or identical DNA sites in vitro

\footnotetext{
${ }^{1}$ The order of these authors is arbitrary.

2Department of Molecular Biology, University of Princeton, Princeton New Jersey, 08544-1014 USA; ${ }^{3}$ Brookdale Center for Molecular Biology, Mount Sinai School of Medicine, New York, New York 10029-6574 USA.
}

(Desplan et al. 1988; Hoey and Levine 1988), some of the distantly related HDs have been shown to have distinct DNA-binding specificities. Systematic analyses of the amino acid sequences in the recognition helices have revealed that a single change at position 9 in the recognition helix is sufficient to change the target gene specificity of Drosophila homeo proteins in yeast (Hanes and Brent 1989), in vitro (Treisman et al. 1989; PercivalSmith et al. 1990), and in flies (Schier and Gehring 1992). Structural studies on the Antennapedia $(A n t p)$ and engrailed (en) HD-DNA complexes have confirmed that the ninth residue of the recognition helix makes critical contacts with specific bases in the major groove (Kissinger et al. 1990; Otting et al. 1990). However, many HD proteins that have identical recognition helices have differential functions in development (Kuziora and McGinnis 1989; Gibson et al. 1990; Mann and Hogness 1990; for review, see Hayashi and Scott 1990), indicating that residues outside of the recognition helix may as well contribute to DNA binding and/or functional specificities.

For the characterization of the biologically functional amino acids of the Antp-class HDs, the pair-rule gene fushi tarazu $(f t z)$ provides an excellent model system. The $f t z \mathrm{HD}$ amino acid sequence is identical to that of Antp HD at 50 of 60 positions and seems to interact with Antp-class target sites in an almost identical manner to that of Antp $\mathrm{HD}$, as demonstrated by chemical interference experiments (Percival-Smith et al. 1990). Owing to the compact structure of its genetic unit, $f t z$ provides a 
simple system that allows functional assessment of various $\mathrm{HD}$ mutations in vivo. A relatively short DNA fragment of $\sim 10 \mathrm{~kb}$ that contains $6.1 \mathrm{~kb}$ of $5^{\prime}$ enhancer and promoter elements, as well as the coding and the $3^{\prime}$ trailer sequences, is able to rescue $f t^{-}$embryos to adulthood when introduced into flies by P-element-mediated transformation (Hiromi et al. 1985).

We have thus utilized this gene rescue system as a complementation assay to monitor the activity of mutations in and around the HTH of the $f t z$ protein in vivo. To investigate the molecular basis of the phenotypic defects observed in transgenic flies, the mutated proteins were also tested for their trans-activation activity in Drosophila tissue culture cells and for their DNA-binding activity to an Antp class target site in vitro. We show that (1) the HTH of the ftz HD can be heavily mutated without abolishing $f t z$ function in vivo; (2) a particular set of amino acids outside of the recognition helix of the $f t z$ HTH motif controls efficient target site recognition both in vitro and in vivo; and (3) the activities of the different mutants are similar when monitored by the three different assay systems used in this study. The information derived from a given mutation is, however, increased by the qualitative and quantitative differences of the different assay systems.

\section{Results \\ Gene rescue by chimeric proteins}

The $f t z-S c r(f t z 4)$ and the $f t z-m s h(f t z 5)$ chimeras were constructed using the XmnI and BglII sites, which are conserved in ftz (Laughon and Scott 1984), Sex combs reduced (Scr) (LeMotte et al. 1989) and muscle segment homeobox (msh) (Robert et al. 1989; B. Jacq, U. Walldorf, and W.J. Gehring, in prep.) homeo box sequences. These fusions introduce 5 and 19 amino acid changes, respectively, into the $f t z \mathrm{HD}$. However, the ninth position of the recognition helix (Gln 50; helix 3 ) is conserved between the three genes (Fig. 1B). An in-frame deletion in the $f t z \mathrm{HD}$ has also been constructed $(f t z \Delta \mathrm{HD})$.

Transgenic lines were established for the $f t z^{+}, f t z 4$, $f t z 5$, and $f t z \Delta \mathrm{HD}$ constructs, and their abilities to rescue $f t z$ mutant embryos was assayed in vivo as described in Materials and methods. About half of the $f t z^{+}$transformant lines obtained with the P-element pCrfl (Fig. 1A) rescued a $f t z^{9 H 34} / f t z^{9093}$ mutant background to adulthood (see Table 1 and comments below). The five amino acid changes in $f t z 4$ did not affect the functionality of the chimeric protein, as most of the $f t z 4$ transformant lines also gave rescue to adulthood in the $f t z$ rescue assay (see Table 1).

None of the $f t z 5$ and $f t z \Delta H D$ lines were able to complement a $f t z^{-}$mutant. However, the inspection of the cuticle of $\mathrm{ftz} 5 /+; \mathrm{tz}^{9 \mathrm{H} 34} / \mathrm{ftz}^{9093}$ embryos indicated that the 19 amino acid changes present in $f t z 5$ did not completely abolish $f t z$ activity, because such individuals frequently showed a partial rescue of the $f t z$ denticle belt pattern (cf. Fig. 2,B with C-E). Furthermore, embryos carrying two copies of the $f t z 5$ gene showed an improved cuticular rescue phenotype (Fig. 2F; see also Fig. 3), although up to three copies of the $f t z 5$ gene still failed to rescue a $f t z^{-}$embryo to adulthood. In contrast, all $f t z \Delta \mathrm{HD}$ lines produced an apparent $\mathrm{ftz}$ pair-rule phenotype, as did all five transformant lines that harbor a destructive frameshift mutation in the $f t z 5$ context at position 45 of helix 3 (data not shown). Retention of partial activity of the $f t z 5$ gene is also supported by the fact that transgenic flies expressing the $f t z 5$ gene under the control of the heat-inducible $h s p 70$ promoter produced a socalled anti-ftz phenotype (Struhl 1985; Ish-Horowicz et al. 1989), when 2.5- to 3.5-hr-old embryos were heatshocked for $20 \mathrm{~min}$, although the frequency was considerably lower than that observed in control heat shock $\mathrm{ftz}^{+}$and $\mathrm{ftz} 4$ lines (see Fig. 2I,J). These results indicate that $f t z 5$ is a hypomorphic $f t z$ allele, whose phenotype is dependent on its gene dosage.

The 19 amino acid changes introduced into the $f t z$ protein by the construction of the $f t z 5$ allele raised the possibility that the cause for the reduced activity could be protein instability, possibly owing to the change in the composition of the hydrophobic core of the ftz protein (see Fig. 1B; for review, see Pakula and Sauer 1989). However, the $f t z 5$ protein could be detected immunologically in the nuclei of developing $f t z 5 ; f t z^{9 H 34} / f t z^{w 2 O} \mathrm{em}-$ bryos, and the $f t z$ stripe pattern was maintained approximately as long as the wild-type pattern (cf. Fig. 4,K with L). Furthermore, ftz5 expression was detected in the embryonic central nervous system with the same intensity and for the same period of time as the wild-type protein (data not shown), indicating that ftz5 is properly expressed and localized in Drosophila embryos. Although these experiments cannot rule out minor differences in protein stability between $f t z^{+}$and $f t z 5$, they support the view that differential stability is not responsible for the defect of the $f t z 5$ allele.

\section{Comments on the in vivo $\mathrm{ftz}$ rescue assay}

Several points are worth noting regarding the general features of the $f t z$ complementation assay. First, Hiromi et al. (1985) had shown that one copy of the transformation vector prf 20 corresponding to the P-element $\mathrm{P}\left[\mathrm{ry}^{+}{ }^{+}, \mathrm{ftz} G\right]$ could rescue the lethality of the $f t z$ mutation in eight of eight independent transformant lines tested. In this construct, the rosy $\langle r y|$ gene, which serves as a transformation marker, and the $f t z$ gene are transcribed in tandem. Transgenic flies harboring prf 19 , a transformation vector in which the $r y$ gene and the $f t z$ gene are transcribed in opposite orientations (Y. Hiromi, unpubl.), gave rescue only in three of six established lines (see Table 1). One may explain this difference compared with prf 20 by the fact that the $f t z$ control elements could be more exposed to nearby silencer elements. The different orientation of transcription of the ry and the $f t z$ genes in the two constructs could also influence $f t z$ activity. The transgenic lines obtained with the newly constructed transformation vector pCrf 1 (see Fig. 1A) showed a rescue frequency 


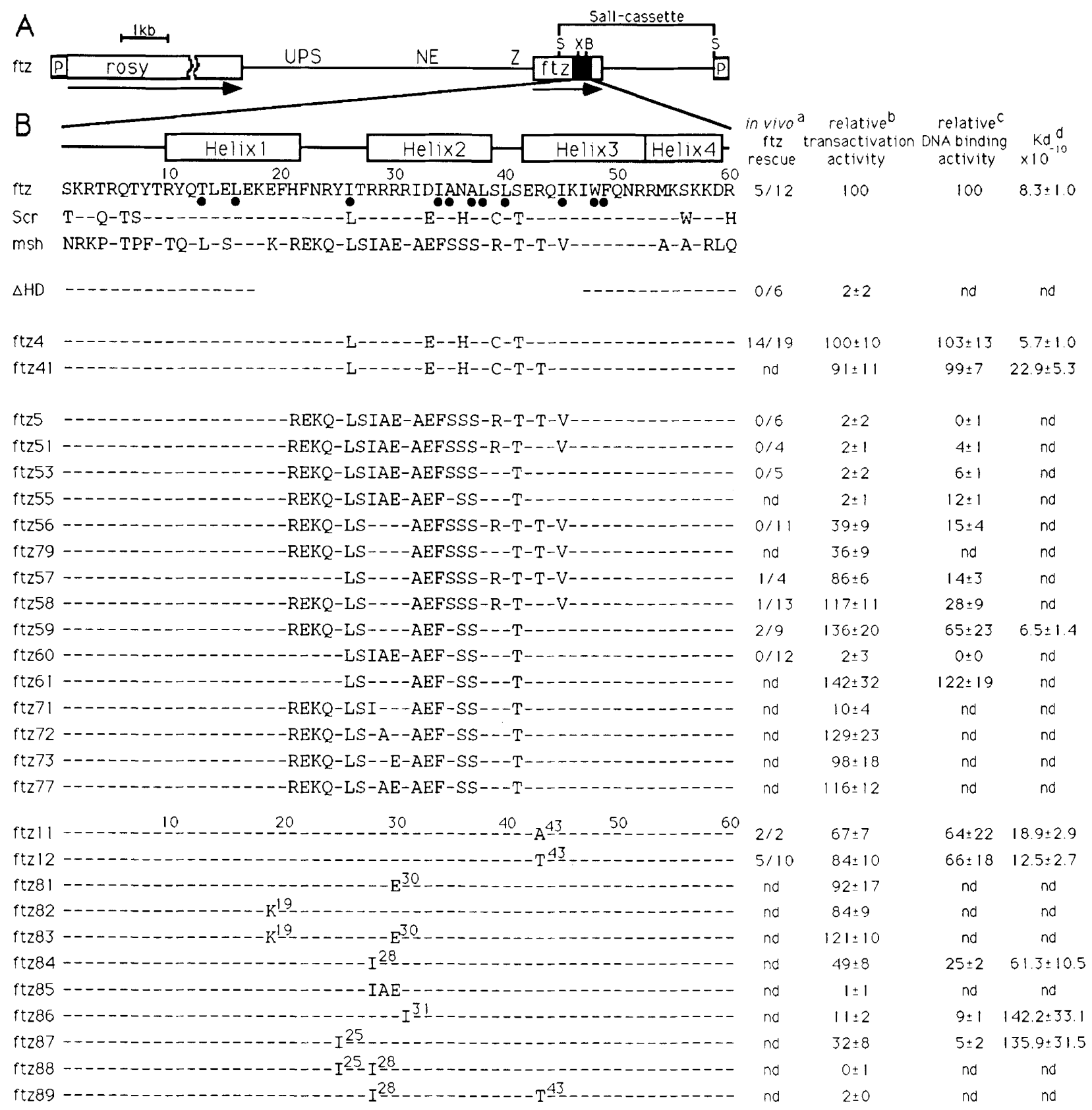

Figure 1. Summary of mutants presented in this study. (A) Structure of the $\mathrm{P}\left[\mathrm{ry}^{+}{ }^{+}, \mathrm{ftz}{ }^{+}\right.$) element of pCrfl. A 10-kb KpnI fragment was cloned into the Carnegie-20 derivative $\mathrm{pC} 20 \mathrm{~K}$ in the orientation indicated (for details see Materials and methods). (UPS) Upstream element; (NE) neurogenic element; (Z) zebra element (Hiromi et al. 1985); (S) SalI; (X) XmnI; (B) BglII. Only relevant restriction sites are indicated for $\mathrm{XmnI}$ and $\mathrm{Bg} / \mathrm{II}$. Arrows indicate the direction of transcription of the $\mathrm{ry}^{+}$and the $f t z^{+}$genes. The solid box in the $f t z$ gene represents the homeo box. $(\mathrm{P}) \mathrm{P}$ elements. $(B)$ Amino acid sequences and activities of the mutant $f t z$ HDs. The locations of the four $\alpha$-helices are drawn according to Qian et al. (1989). The original sequences of Scr and msh HDs are also shown along with the wild-type $f t z$ sequence for comparison. (O) The amino acids forming the hydrophobic core of the HD (Qian et al. 1989; Billeter et al. 1990). The activities and $K_{\mathbf{d}}$ values determined by the three assay systems are listed at right. $(a)$ Complete ftz rescue to adult stage. The number of lines that rescued $f z^{9 H 34} / f t z^{9093}$ embryos to adult stage is presented over the total number of lines examined. The survival indices of the rescuing lines are presented in Table 1. (b) Relative trans-activation activity in Schneider cells. The percent wild-type activity was calculated based on the stimulation of the reporter CAT gene expression under the condition where wild-type protein stimulated the reporter gene expression by 19 -fold. $|-|<5 \% ;|+| 6-25 \% ; 1++|26-50 \% ;|+++|51-75 \% ;|++++\mid>75 \%$. Values were determined in at least three independent transfection experiments. The CAT activity was normalized against an internal control (see Materials and methods). (c) Relative in vitro DNA-binding activity of the 73-amino-acid mutant HD peptides. The activity is presented as percent wild type. Experiments were repeated at least twice. $(d) K_{\mathrm{d}}$ value of the purified HD peptide. The peptides were expressed in E. coli and purified to near homogeneity. Values were calculated from saturation band-shift experiments using an Antp-class binding site (BS2-18; Müller et al. 1988). (nd) Not determined. 
Table 1. Survival indices of the rescuing lines in the $\mathrm{ftz}$ complementation test

\begin{tabular}{|c|c|c|c|c|}
\hline P element & Line & Linkage $^{a}$ & SI $\left(\left.f t z^{9093}\right|^{\mathrm{b}}\right.$ & SI $\left(f t z^{w 20}\right)^{c}$ \\
\hline $\mathrm{P}\left[r y^{+}, f t z^{+}\right]^{\mathrm{d}}$ & $\begin{array}{l}1.5 .1 \\
1.8 .1 \\
1.13 .3\end{array}$ & $\begin{array}{l}\text { X } \\
\text { II } \\
\text { II }\end{array}$ & $\begin{array}{l}0.61 \\
0.32 \\
0.68\end{array}$ & $\begin{array}{l}0.72 \\
0 \\
0.69\end{array}$ \\
\hline $\mathrm{P}\left[r y^{+}, f t z^{+}\right]^{e}$ & $\begin{array}{l}3.43 .2 \\
j 3.7 \\
j 3.8 \\
j 3.17 \\
j 3.18\end{array}$ & $\begin{array}{l}\mathrm{II} \\
\mathrm{II} \\
\mathrm{X} \\
\mathrm{X} \\
\mathrm{CyO}\end{array}$ & $\begin{array}{l}0.30 \\
0.30 \\
0.31 \\
0.56 \\
0.87\end{array}$ & $\begin{array}{l}0.11 \\
0.11 \\
0 \\
\text { ND } \\
0.48\end{array}$ \\
\hline $\mathrm{P}\left[r y^{+}, f t z 4\right]$ & $\begin{array}{l}4.26 .1 \\
4.26 .1 \mathrm{j} 1 \\
\mathrm{j} 4.1 .1 \\
\mathrm{j} 4.14 .1 \\
\mathrm{j} 4.18 .2\end{array}$ & $\begin{array}{l}\text { IV } \\
C y O \\
\mathrm{X} \\
S p \\
S p\end{array}$ & $\begin{array}{l}0.78 \\
0.46 \\
0.24 \\
0.21 \\
0.33\end{array}$ & $\begin{array}{l}0.81 \\
0.08 \\
0 \\
0 \\
0.04\end{array}$ \\
\hline $\mathrm{P}\left[r y^{+}, f t z 57\right]$ & $\begin{array}{l}19.39 .5 \\
19.68 .2\end{array}$ & $\begin{array}{l}X \\
\text { II }\end{array}$ & $\stackrel{+}{0.05}$ & $\begin{array}{l}0 \\
0\end{array}$ \\
\hline $\mathrm{P}\left[\mathrm{ry}^{+}, f t z 58\right]$ & $\begin{array}{l}20.16 .3 \\
20.17 .4\end{array}$ & $\begin{array}{l}\text { II } \\
\text { II* }\end{array}$ & $\stackrel{+}{0.27}$ & $\begin{array}{l}0 \\
+\end{array}$ \\
\hline $\mathrm{P}\left[r y^{+}, f t z 59\right]$ & $\begin{array}{l}21.48 .4 \\
21.76 .3 \\
21.84 .6\end{array}$ & $\begin{array}{l}\text { II } \\
\text { II }^{\star} \\
\text { II }^{\star}\end{array}$ & $\begin{array}{c}+ \\
0.40 \\
0.30\end{array}$ & $\begin{array}{l}0 \\
0.19 \\
0.13\end{array}$ \\
\hline $\mathrm{P}\left[r y^{+}, f t z 11\right]$ & $\begin{array}{l}11.44 .1 \\
11.44 .2\end{array}$ & $\begin{array}{l}\mathrm{X} \\
\mathrm{II}\end{array}$ & $\begin{array}{l}0.25 \\
0.35\end{array}$ & $\begin{array}{l}0 \\
0\end{array}$ \\
\hline $\mathrm{P}\left[r y^{+}, f t z 12\right]$ & $\begin{array}{l}\mathrm{j} 15.7 \\
\mathrm{j} 15.15 \\
\mathrm{j} 15.16 \\
15.15 .3 \\
15.23 .4\end{array}$ & $\begin{array}{l}\mathrm{CyO} \\
\mathrm{CyO} \\
\mathrm{CyO} \\
\text { II } \\
\text { II }\end{array}$ & $\begin{array}{l}0.49 \\
0.66 \\
0.26 \\
0.15 \\
0.41\end{array}$ & $\begin{array}{l}0.32 \\
0.66 \\
0 \\
0 \\
0\end{array}$ \\
\hline
\end{tabular}

Survival index (SI) was calculated as described in Materials and methods. $1+\mid$ Occasional survivors in independent experiments. For $\mathrm{P}\left[\mathrm{ry}^{+}, f \mathrm{tz} 4\right]$, only 5 of the 14 rescuing lines are shown. (ND) Not done.

${ }^{a}(\mathrm{X}) \mathrm{X}$ chromosome; (II) second chromosome; (CyO) CyO balancer chromosome; (Sp) sternopleural (homozygous lethal second chromosome marker); (*) line carrying two inserts on a single chromosome, as shown by genomic Southern blotting. bSurvival indices in $f z^{9 H 34} / f t z^{9093}$ background.

'Survival indices in $f t z^{9 H 34} / f t z^{\text {w2O }}$ background.

${ }^{\mathrm{d}} f z^{+}$on prf19 (Y. Hiromi, unpubl.). The orientation of the $f t z+$ gene in this $P$ element is opposite to the one shown in Fig. 1 (see text).

eftz ${ }^{+}$on pCrfl (see Fig. 1). This vector was used for the mutational analysis presented in this paper.

similar to prf19 (see Table 1), even though the plasmid structure differs from prf20 only in a slightly different polylinker region. We have no reasonable explanation for this observation.

Second, for the $f t z$ rescue assay we have used two different transheterozygous mutant backgrounds (see Table 1). It is evident that the calculated survival indices (SIs) are generally higher in the $f t z^{9 H 34} / f t z^{9093}$ than in the $f t z^{9 H 34} / f t z^{\text {w2O }}$ background. The same tendency is also observed regarding the embryonic rescue phenotype in the two mutant backgrounds (data not shown). This phenomenon can be interpreted in light of the available im- munolocalization experiments. $f t z^{9 H 34}$ and $f t z^{\text {w2O }}$ are $f t z$ null-alleles (see also Materials and methods). However, as shown in Figure $4 \mathrm{M}, \mathrm{ftz}^{9 \mathrm{O} 93}$ (Jürgens et al. 1984) homozygous embryos establish a seven-striped, yet abnormal, $f t z$ staining pattern. The $f t z$-dependent even-numbered en (DiNardo et al. 1988; Lawrence and Johnston 1989) stripes are not formed (data not shown). In a $\mathrm{ftz}^{9 \mathrm{H34}} / \mathrm{ftz}^{9093}$ background, the $\mathrm{ftz} \mathrm{z}^{9093}$ protein therefore could contribute to the activation of the $f t z$ transgene, although it might not affect the potential of the transgene to activate transcription of the segment polarity gene $e n$.

Finally, recent studies have revealed that the sevenstripe pattern emerging from the transcription of $\mathrm{P}\left[\mathrm{ry}^{+}, \mathrm{ftz} G\right]$ differs temporally and spatially from that observed for the endogenous $f t z$ gene (L. Pick, in prep.). This may indicate that the $10-\mathrm{kb}$ fragment characterized by Hiromi et al. (1985) does not contain all necessary regulatory elements to direct the full $\mathrm{ftz}$ expression pattern. On the other hand, it is possible that the $f t z$ gene can only be properly expressed when located in the context of the entire ANT complex.

\section{Establishment of $\mathrm{ftz}$ and en expression patterns in $\mathrm{ftz} 5$ embryos}

ftz (Wakimoto and Kaufman 1981; Laughon and Scott 1984) and en (Kornberg 1981; Fjose et al. 1985) are components of the regulatory hierarchy establishing the metameric pattern of the Drosophila embryo (for review, see Howard 1990). The product of the pair-rule gene $f t z$ regulates the expression of the segment polarity gene en in the even-numbered parasegments either directly or indirectly. In the absence of $f t z$ activity, no even-numbered en stripes are formed (DiNardo et al. 1988). The striped $f t z$ expression is regulated by two cis-regulatory elements located $5^{\prime}$ of the $f t z$ gene: the zebra and the $f t z$-dependent, enhancer-like upstream element /see Fig. 1A; Hiromi et al. 1985; Hiromi and Gehring 1987; Pick et al. 1990; Schier and Gehring 1992).

In an attempt to further characterize the molecular defects of the $f t z 5$ allele, we examined the expression patterns of $f t z$ (Carroll and Scott 1985) and en (DiNardo et al. 1985) by antibody staining in a $\mathrm{ft}^{9 \mathrm{H} 34} / \mathrm{ftz}^{\mathrm{w2O}} \mathrm{mu}-$ tant background and compared it with wild-type and $f t z \Delta \mathrm{HD} /+; f t z^{9 H 34} / f t z^{\mathrm{w} 2 O}$ individuals. The hypomorphic character of $f t z 5$ is evident at cellular blastoderm (Fig. 4A-D). ftz expression levels are drastically reduced in $f t z \Delta \mathrm{HD}$, one-copy and two-copy ftz 5 embryos as compared with wild type. The uneven and weak $f t z$ stripe pattern is almost entirely preserved in one-copy ftz $5 \mathrm{em}$ bryos during early germ-band extension (Fig. 4F). In contrast, at that stage, the intensity of staining in two-copy $f t z 5$ embryos is almost wild-type-like (Fig. 4G), emphasizing the dosage-dependent character of the ftz5 gene. This expression is maintained nearly as long as in wildtype embryos and contrasts to the rapid fading in $f t z \Delta \mathrm{HD}$ and single-copy $f t z 5$ embryos (cf. ftz expression patterns in Fig. 4I-L). 
Figure 2. Embryonic rescue phenotypes of $f t z 5$ and its derivatives. Ventral cuticular patterns of first instar larva are presented. $(A)$ Wild-type denticle belt pattern. (T1-T3) Thoracic denticle belts; (Al-A8) abdominal denticle belts. $(B) f_{t z}{ }^{9 H 34} /$ $f t z^{9093}$ larva. The size of the $f t z$ larva is reduced owing to the deletion of alternate segments. $(C-E)$ Typical examples of the IAE group $(f t z 5, f t z 51, f t z 53, f t z 60)$ larvae carrying one copy of the transgene. Their transgenes harbor the tripeptide Ile $\mathrm{Ala}$ Glu (IAE) substitutions at position 28-30. Arrowheads indicate partially or completely restored denticle belts. The larvae shown in $C-E$ are preparations from $f t z 60$ (line 22.31.1). $(F)$ Example of a larva carrying two copies of the $f t z 5$ gene (line 5.85.5). Note the improvement of the denticle belt pattern. $(G, H)$ Typical examples of the RRR group $(f t z 56, f t z 57, f t z 58, f t z 59)$ larvae. Their transgenes gain the Arg stretch at positions 28-30. (G) An example from $f t z 56$ (line 18.37.1); $(H)$ an example from $f t z 57$ (line 19.10.3). (I,I) Anti-ftz phenotypes obtained with $f t z$ (line 7.4.1) and ftz5 (line 9.23.1) heat shock lines. Note the reciprocal denticle belt pattern compared with $B$.

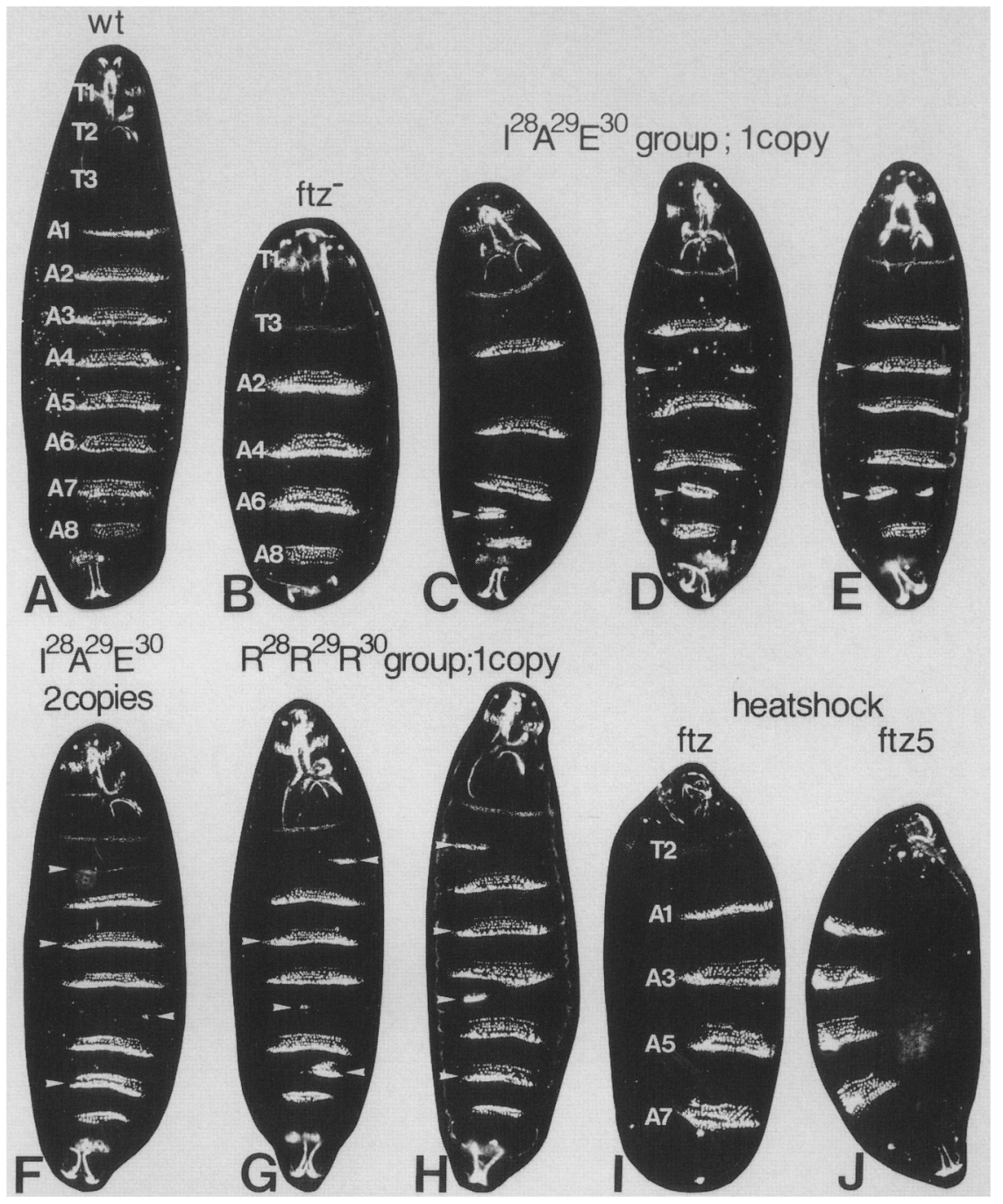

At the germ-band elongation stage, en is expressed in 14 evenly spaced stripes along the anterior-posterior axis (Fig. 4P; DiNardo et al. 1985). While even-numbered en stripes were completely absent in the $f t z \Delta \mathrm{HD}$ embryos (Fig. 4I), the en patterns established in one- and two-copy $f t z 5$ embryos correlate well with the dosage dependence found for the $f t z$ expression pattern (cf. Fig. $4 \mathrm{~N}$ with $\mathrm{O}$ ). In the former case, only patches of en-expressing cells can be detected at some of the expected positions (triangles in Fig. 4N). In the latter, 13 en stripes were formed (Fig. 4O). The second en stripe was almost completely missing, most probably the result of the insufficient expression levels of the first $f t z$ stripe in the preceding stages of development (open triangles in Fig. $4 \mathrm{~N}, \mathrm{O}$ ). The expression of the other even-numbered en stripes is mostly restricted to the ventral side of the embryo. Occasionally, patches of en-expressing cells can be observed more laterally. This may be a direct cause of the initially low $\mathrm{ftz}$ protein levels and might imply that higher $\mathrm{ftz}$ protein levels are required to transcriptionally activate en expression laterally. On the other hand, the eighth en stripe looks more normal (data not shown). This correlates well with the enhanced staining in the fourth $\mathrm{ftz}$ stripe at the cellular blastoderm stage (arrowhead in Fig. 4C) and with the preferential rescue of the denticle belt in the third abdominal segment later in the embryogenesis of ftz5 individuals (see Fig. 3).

An intriguing aspect of the en expression pattern in $f t z 5$ embryos is the uneven spacing between neighboring en stripes established after the onset of germ-band extension (cf. the distance between arrows and triangles in Fig. 4N-P|. The width of even-numbered parasegments was narrower in $f t z 5$ embryos than normal because the distance between en stripes 2 and 3, 4 and 5, and 6 and 7 became smaller than in wild type. The irregular spacing was less apparent in the posterior parts of the embryo. A similar, although complementary, pattern of en expression has been described for even-skipped (eve) hypomorphic (DiNardo and O'Farrell 1987; Frasch et al. 1988) and ftz hypermorphic alleles (Kellerman et al. 1990), which express en stripes 1 and 2, 3 and 4, 5 and 6, and so on, closer together. It thus appears that the correct position- 


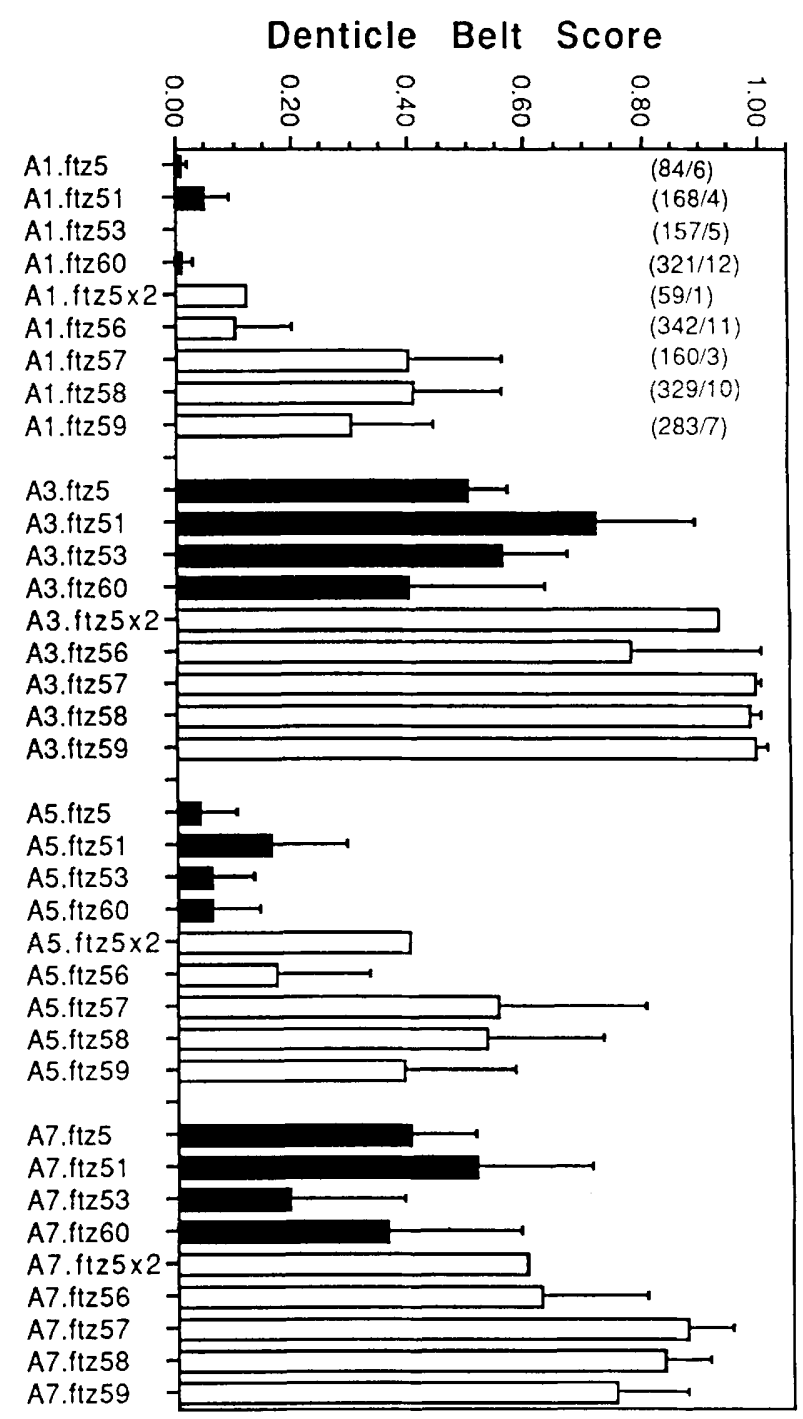

Figure 3 Statistical analysis of embryonic rescue phenotypes. The denticle belt patterns of first-instar larvae of $f t z 5$ and $f t z 5$ revertants were analyzed for the potential of the mutant proteins to rescue the $f t z$ embryonic phenotype. Denticle belts in the abdominal segments Al, A3, A5, and A7 were scored individually in a $f z^{9 H 34} / f z^{9093}$ background as described in Materials and methods. The rescue data for each transgenic line are plotted horizontally for each denticle belt individually. Standard deviations are indicated by thin lines at the end of each bar. The vertical axis lists the $f t z$ alleles and the denticle belts $A l$, A3, A5, and A7. All six $f t z \Delta$ HD lines analyzed did not show any rescue and are not included. (Solid bars) Ile-28 Ala-29 Glu-30 (IEA) group mutants (ftz5, ftz51, ftz53, and ftz60); (open bars) Arg-28 Arg-29 Arg-30 (RRR) group mutants ( $f t z 56, f t z 57, f t z 58$, and $f t z 59)$. The denticle belt scores of the two-copy $f t z 5$ larvae are also shown by open bars (data for line 5.85.6 are shown). Numbers in parentheses (top right) indicate the number of embryos that were scored showing a partial rescue phenotype and the number of lines analyzed per mutant. Only transgenic lines with SI values $<0$ were included in this analysis.

ing of en stripes and therefore of the parasegmental boundaries is dependent on a proper dosage balance between the pair-rule genes eve and $f t z$.
Amino acid changes at the amino terminus of the HTH improve $\mathrm{ftz}$ activity in transgenic flies

To specify the important residues in $f t z 5$ responsible for the reduced $f t z$ activity in vivo, a series of revertants were constructed and tested in transgenic flies. Furthermore, the second position of the recognition helix was mutated in the $f t z$ wild-type context (ftzl l, ftz12), as it represents the only exposed residue on the surface of helix 3 that is different in $f t z$ and $f t z 5$ (see Fig. 1B). Reversions of $f t z 5$ to wild type at exposed residues at the amino terminus of the recognition helix, or buried residues contributing to the hydrophobic core, did not improve the rescue activity (Fig. 1B, ftz51, ftz53). Even more extensive reversions did not change the situation (ftz60). The cuticular preparations obtained with these rescue negative lines showed a similar embryonic cuticular phenotype as $f t z 5$ (see Fig. 3). In contrast, transformant lines harboring constructs that gained a consecutive stretch of 3 arginines at the amino terminus of the HTH motif (ftz56, ftz57, ftz58, ftz59) showed moderate to drastic improvements in the embryonic cuticular patterns (see Figs. 2G,H and 3). Moreover, one (albeit with very low SI values) or two copies of these constructs were able to rescue $f t z$ embryos to adulthood (Fig. 1B; Table 1). However, the arginine stretch was not sufficient for a drastic increase in the rescue efficiency (ftz56). Additional reversions either in the loop between helix 1 and helix 2 (ftz57) or at the second position of helix $3(f t z 58)$ were required. Further reversions toward the wild-type situation did not significantly improve the activity of the $f t z$ protein in vivo $(f t z 59)$. Mutants with single amino acid changes at the second position of the recognition helix ( $f t z 11$ and $f t z 12)$ were still able to rescue $f t z$ embryos to adulthood.

\section{Cell culture experiments confirm}

the requirements of the arginine stretch for $\mathrm{ftz}$ activity

$f t z$ has been shown to be a transcriptional activator in Drosophila tissue culture cells (Jaynes and O'Farrell 1988; Han et al. 1989; Winslow et al. 1989). To further dissect the HTH motif of the $f t z \mathrm{HD}$, we examined the transcriptional stimulatory activities of the mutant $\mathrm{ftz}$ proteins in Schneider cells (S1W220; see Materials and methods). $f t z$ protein producer plasmids were cotransfected with a reporter plasmid that has 11 copies of the Antp-class binding sites BS2 (Müller et al. 1988) upstream of a $h s p 70-$ chloramphenicol acetyl transferase (CAT) fusion gene. Consistent with the observations in transgenic flies, $f t z 5$ was defective in trans-activation in Schneider cells while $f t z 4$ retained wild-type activity (see relative trans-activation activities in Fig. 1B). The complete activity retention by $f t z 4$ protein agreed well with the observation that full-length $S c r$ protein itself stimulated the same reporter gene expression in Schneider cells (data not shown). We were, however, unable to detect the expression in Schneider cells of any of our $\mathrm{ftz}$ constructs, either by direct immunostaining or Western blotting, presumably because of the rapid turnover rates 


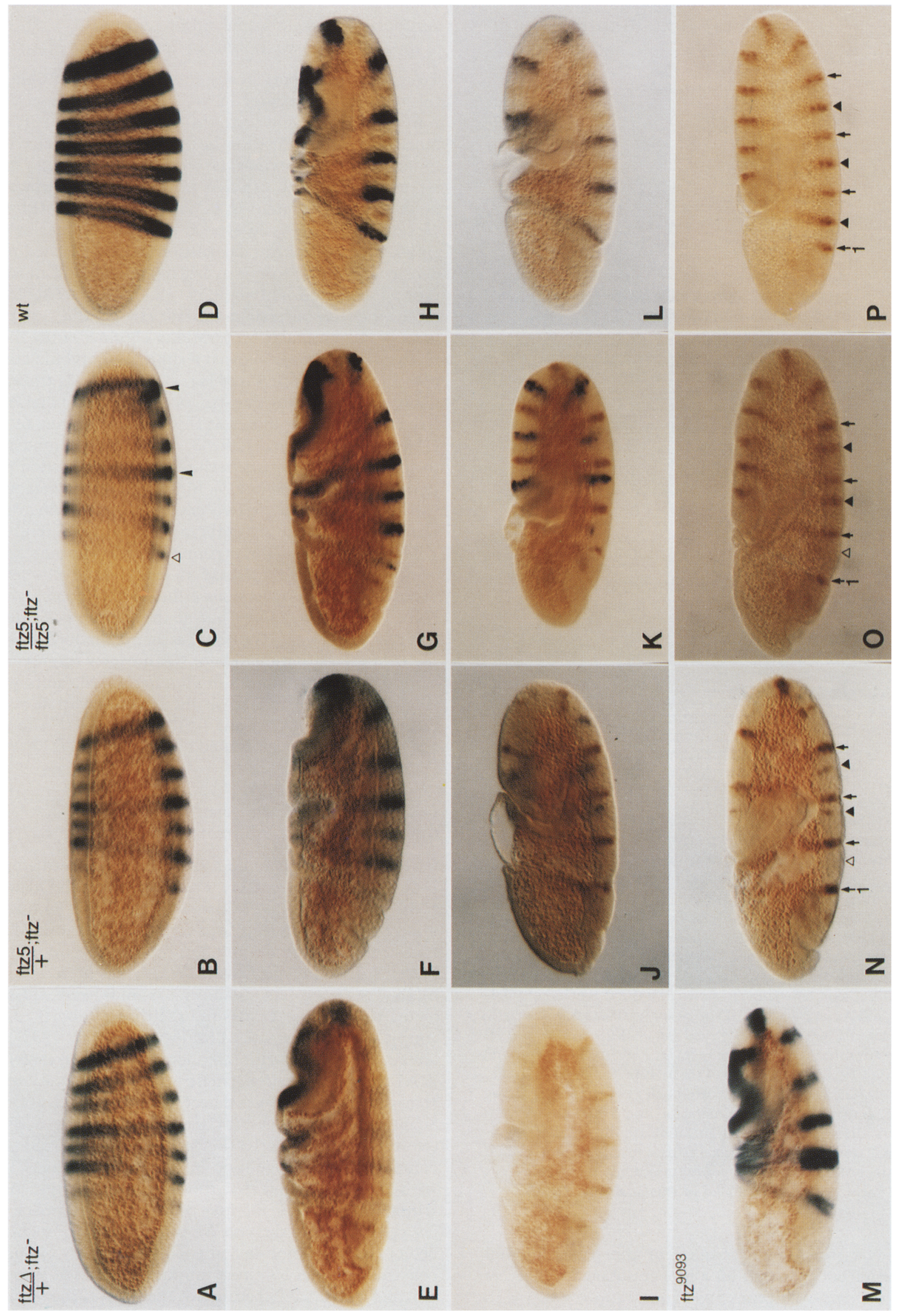


of $f t z$ RNA and protein in Drosophila cells (Edgar et al. 1987; Kellerman et al. 1990).

The tissue culture assay data for the $f t z 5$ back-mutations confirmed the requirement for the arginine stretch at the amino terminus of the HTH. The effect of the reversion of the arginine stretch was drastic as demonstrated by the mutant pairs $f t z 5$ and $f t z 56, f t z 51$ and $f t z 58, f t z 55$ and $f t z 59$, and $f t z 60$ and $f t z 61$ (see Fig. 1B). A limited substitution of the 3 arginines in the wild-type context completely abolished $f t z$ trans-activational activity (ftz85), indicating that the requirement for the arginine stretch is intrinsic for $\mathrm{ftz}^{+}$protein function.

\section{Arg-28 restores ftz trans-activation}

activity in combination with other key residues

A computer analysis of the Antp HD structure /Qian et al. 1989; Billeter et al. 1990) suggested that Arg-30 in the Arg stretch in helix 2 forms an ion-pair bridge with Glu19 in helix 1 . Interestingly, the $f t z 5$ mutation substitutes Glu for Arg-30, breaking this helix 1-helix 2 bridge, whereas an ion pair is present in the original msh protein. To examine the role of this helix-helix bridge in stabilizing the alignment of the two helices, we introduced a single Glu mutation at position 30 (ftz73) in the ftz59 context, which is fully active both in flies and in Schneider cells. We also introduced single mutations into wild-type $f t z$ context that would disrupt the helixhelix bridge by like-like combinations of electrical charges (ftz81 and $f t z 82)$, as well as a double mutation that reverses the ion-pair combination as found in msh (ftz83). However, none of these mutations significantly affected $\mathrm{ftz}$ trans-activation activity, indicating that a functional configuration of the $f t z \mathrm{HD}$ is not dependent on the charge stabilized interaction between the side chains of amino acids 19 and 30.

On the other hand, changing Arg-28 to Ile in the ftz59 context led to significant suppression of the trans-activation activity (ftz 71 ), and a single reversion of Ile-28 to Arg in $f t z 55$ completely restored wild-type activity (ftz77). The importance of Arg-28 to $\mathrm{ftz}$ function was further confirmed by a single substitution of Arg-28 to Ile in the wild-type context (ftz84), which resulted in $\sim 50 \%$ reduction of trans-activation activity.

However, the activity of $f t z 56$ was still weak despite the preservation of Arg-28. It was not improved by a single back-substitution of Arg-39 to Ser (ftz79) in the turn between helix 2 and 3 , where some of the $\lambda$ phage positive control mutations have been mapped (Hochs- child et al. 1983). On the other hand, $f t z$ activity was stimulated either by the reversion at position 43 (cf. activities of $f t z 56$ and $f t z 58$ ) or at residues 21-24 (ftz57). The combined contribution of Arg-28 and Arg- 43 was further supported by the complete abolishment of $f t z$ trans-activation activity by simultaneous mutations for these two residues (ftz89) while single substitutions for Arg-43 suppressed activity only weakly (ftz11, ftz12).

The result that both Arg-28 and Arg-43 are required for optimal $f t z$ trans-activation activity agrees well with the structural information on the Antp HD-DNA complex, which is likely to be preserved for the $f t z$ HD-DNA complex. The topological positions of Arg-28 and Arg-43 in the Antp HD-DNA complex (Otting et al. 1990) suggest that these two residues are directly involved in HDDNA backbone interactions. Close to Arg-28, DNA backbone contacts by the highly conserved Tyr- 25 and Arg-31 have been reported for the en and Antp HD-DNA complexes (Kissinger et al. 1990; Otting et al. 1990; see Table 2). Consistent with this, substitutions for Tyr-25 and Arg-31 significantly suppressed $f t z$ transcriptional activity (ftz86 and $f t z 87$ ). Moreover, a double mutation for Tyr-25 and Arg-28 completely abolished trans-activation activity (ftz88), revealing the importance of the multiple DNA-backbone contacts at the amino terminus of the $f t z$ HTH.

\section{In vitro studies reveal the requirement of the in vivo-defined key residues for DNA binding}

To directly determine the residues required for efficient target site recognition and to quantify their contribution to it, in vitro DNA band-shift experiments were performed. Full-length protein was expressed in reticulocyte lysates (Fig. 5A) and its binding activity to the Antpclass target site BS2 (Müller et al. 1988) was examined (Fig. 5B). Despite the identity of the ninth residue in the recognition helices (see Fig. 1B), ftz5 and msh proteins did not bind the target DNA (Fig. 5B, lanes e,g), whereas wild-type $f t z$ (Fig. 5B, lane b), $f t z 4$ (lane d) and $S c r$ (lane f) proteins did.

The DNA-binding defect of $f t z 5 \mathrm{HD}$ was further confirmed with a 73-amino-acid HD peptide synthesized in vitro. The binding activity of the $f t z 5 \mathrm{HD}$ was undetectable (Fig. 5C, lanes c,e) even after prolonged exposure of the film indicating that it is reduced at least 50 - to 100 fold as compared with wild type (lanes b,d). Mutant HDs that gained the Arg stretch of helix 2 bound the DNA significantly better (Fig. 5C and DNA-binding activities

Figure 4. ftz and $e n$ protein expression patterns in $f t z \Delta \mathrm{HD}$ (line 13.13.1), ftz5 (line 5.85.6), and wild-type embryos. Embryos are shown anterior to the left, ventral side down. $f t z$ protein was detected with a polyclonal anti-ftz serum (Krause et al. 1988) and an alkaline phosphatase-conjugated secondary antibody (dark blue); en was detected with a monoclonal anti-en antibody (Patel et al. 1989) and HRP-conjugated secondary antibody (brown). $(A, E, I) f t z \Delta \mathrm{HD} /+; f t z^{9 H 34} / f t z^{\mathrm{w} 20} ;(B, F, J, N) f t z 5 /+; f t z^{9 H 34} / f t z^{\text {w20 }} ;(C, G, K, O) f t z 5 / f t z 5$; $f t z^{9 H 34} / f t z^{w 20}(D, H, L, P)$ wild type; $(M)$ homozygous $f t z^{9093}$. Compare with the wild-type $f t z$ staining in $H$. $(A-D)$ Cellular blastoderm stage; $(E-H, M)$ early germ-band extension stage; $(I-L)$ mid-germ-band extension stage; $\{N-P\rangle$ extended germ-band stage. Open triangle in $C$ points to the weakly expressed first $f t z$ stripe. Arrowheads in $C$ indicate the slightly enhanced staining of the fourth and seventh $f t z$ stripes. Arrows in $N-P$ point to en stripes $1,3,5$, and 7. The first en stripe is labeled with the number 1 . Open triangles in $N$ and $O$ indicate the second en stripe barely detectable in $f t z 5$ embryos. Solid triangles in $N$ and $O$ point to en stripes 4 and 6 . Note the uneven spacing of the en pattern in $N$ and $O$ compared with $P$. 
Table 2. The DNA backbone contacting amino acids at the amino terminus of the HTH motifs of HDs

\begin{tabular}{lcccc}
\hline & \multicolumn{4}{c}{ Residue } \\
\cline { 2 - 5 } HD & 25 & 28 & 31 & 43 \\
\hline Antp class & Tyr & Arg & Arg $^{\mathrm{a}}$ & Arg \\
Dfd class & - & - & - & - \\
AbdB class & - & - Lys $^{\mathrm{b}}$ & - & - \\
labial class & - & - & - & Thr \\
en class & - & Glu & - & Ala/Ser \\
eve class & - & - & - & Ser/Thr \\
paired class & - & Ile/Val & - & Ala \\
hox-1.5 class & - & - & - & - \\
hox-2.4 class & - & - & - & - \\
caudal & - & Ile & Lys & - \\
cut & - & Val & Ile & - \\
bcd & - & Ala & Leu & Ala \\
MAT $\alpha 2$ & - & Thr & Leu & Ile \\
Oct-1 & Lys & Ser & Ile & Glu \\
\hline Aming acid & sequence &
\end{tabular}

Amino acid sequence data and classification is from Scott et al. (1989). Residue identical to Antp HD is shown by a dash. Amino acid(s) are indicated where the residue is different from Antp HD.

${ }^{a}$ With the exception of hox-11 and $r 5$.

${ }^{b}$ Lysine may be able to make similar DNA backbone contact. in Fig. 1B). This is shown clearly by the comparisons of $f t z 5$ (Fig. 5C, lane e) and $f t z 56$ (lane h), ftz5l (lane f) and $f t z 58$ (lane i), $f t z 55$ (lane g) and $f t z 59$ (lane k), and $f t z 60$ (lane v) and ftz61 (lane w). Binding activity was significantly suppressed by single substitutions for the key residues Arg-28 (ftz84, lane n), Arg-31 (ftz86, lane o), and Tyr-25 (ftz87, lane p).

Single back-mutations at position 43 improved DNA binding, although weakly. Compared with $f t z 5$ (lane e), ftz5l (lane f) showed detectable binding activity. DNAbinding activity was also improved in $f t z 58$ (lane i) compared with $f t z 56$ (lane h), where only Arg-43 is substituted between the two mutants. Moreover, single Ala (ftz11, lane 1 ) and Thr ( $f t z 12$, lane $\mathrm{m}$ ) substitutions at position 43 in the wild-type context suppressed DNAbinding activity.

To determine the binding activities of some of the mutant HDs more precisely, the 73-amino-acid HD peptides were expressed in Escherichia coli and purified to near homogeneity. Many of the $f t z 5$ derivatives were insoluble in bacterial lysates and could not be purified by our standard protocol, but some of the key mutant proteins were purified, and their $K_{\mathrm{d}}$ values were determined (see $K_{\mathrm{d}}$ values listed in Fig. 1B). Those $K_{\mathrm{d}}$ values are in good
Figure 5. In vitro DNA-binding activities of mutant HD proteins. $(A)$ In vitro synthesis of full-length HD proteins. Proteins synthesized in reticulocyte lysate were analyzed by SDS-10\% PAGE. (a) Reticulocyte lysate incubated without RNA template; $(b \mid f t z$ wild type $(c) f t z 4$; (d) $f t z 5$; $(e) S c r ;(f)$ msh. ftz proteins appear as a doublet that may be caused by proteolysis in the lysate. Scr protein migrates faster than standards, probably owing to its amino acid composition (LeMotte et al. 1989|. Positions of known molecular mass markers are indicated (in $\mathrm{kD}) .(B)$ In vitro DNAbinding activities of full-length proteins. The in vitrotranslated full-length proteins were incubated with an Antp site probe $(\mathrm{F} 1-60)$ that has one BS2 site. Bound $(B)$ and free $(F)$ probes were separated through $8 \%$ acrylamide gel in $0.25 \times$ TBE. (a) Lysate incubated without RNA template; $\{b\rangle f t z$ wild type; $(c) f t z$ wild type with specific competitor (100-fold BS2-18); (d) $f t z 4 ;|e| f t z 5 ;(f) S c r ;(g) m s h .(C)$ DNA-binding activity of in vitro-translated mutant $f t z$ HDs. In vitro-synthesized 73-amino-acid $\mathrm{ftz}$ HD was incubated with the F1-60 probe. Probe bound by $f t z \mathrm{HD}$ (small arrowhead) was separated from free $(\mathrm{F})$ probe through $8 \%$ acrylamide gels in $0.25 \times$ TBE. Protein amount was standardized based on $\left.{ }^{35} \mathrm{~S}\right]$ methionine incorporation. $(a)$ Lysate incubated without template RNA; $(b) f t z$ wildtype HD with 117-amino-acid Antp HD (the Antp HD RNA was cotranslated with $f t z \mathrm{HD}$ to serve as an internal control for in vitro translation and DNA binding); (c) ftz5 HD with 117 amino-acid Antp HD; (d) ftz wild type; $(e) f t z 5 ;(f) f t z 51 ;(g) f t z 55 ;(h)$ ftz56; (i) ftz57; (j) ftz58; (k) ftz59; (l) ftz11; (m) ftz12; (n)
A

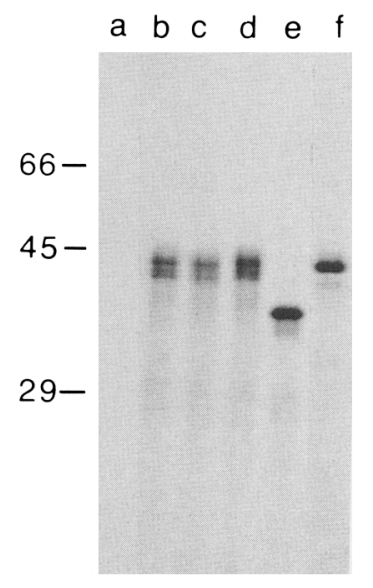

C
B

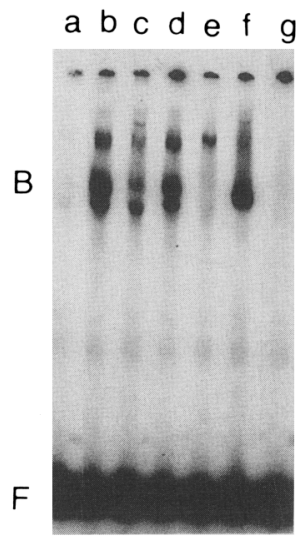

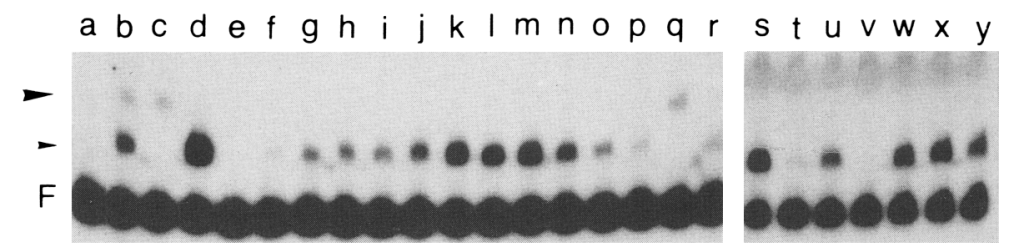
ftz84; $(0)$ ftz86; $(p) f t z 87 ;(q)$ 117-amino-acid Antp HD alone; $(r) f t z$ wild type with specific competitor $(100$-fold BS2-18); $(s) f t z$ wild type; $(t) f t z 53 ;(u) f t z 59 ;(v) f t z 60 ;(w) f t z 61 ;(x) f t z 4 ;(y) f t z 41$. Probe bound by the Antp HD is indicated by the large arrowhead. The amount of $f t z$ HD used in $b$ and $c$ was one-quarter of that used in other lanes. Proteins used in $a-r$ and $s-y$ were synthesized with independent sets of RNA templates. $f t z$ wild type and $f t z 5$ were included in both experiments for comparison. 
agreement with the relative DNA-binding activities determined with the in vitro-synthesized HDs. In particular, single amino acid substitutions at positions 25,28 , and 31 at the amino terminus of the HTH increased the $K_{\mathrm{d}}$ values by 7 - to 17 -fold as compared with wild type.

\section{Discussion}

Mutational analysis of a protein of known function is most instructive when combined with information about its three-dimensional structure. Outstanding examples for the power of such approachs are the detailed studies on the prokaryotic gene regulatory proteins such as $\lambda$ repressor (Sauer et al. 1990). Recent high-resolution nuclear magnetic resonance (NMR) and X-ray crystallographic studies of the Antp (Qian et al. 1989; Billeter et al. 1990; Otting et al. 1990), en (Kissinger et al. 1990), and Mat 22 (Wolberger et al. 1991) HDs provide a solid basis for the interpretation of the increasing number of HD mutations of the homeo protein super family. These structural studies have shown that HDs with highly divergent amino acid sequences can adopt almost congruent folds and that they contact their target DNA in similar ways. In vitro DNA-binding studies on the $f t z$ and Antp HDs also support this view (Affolter et al. 1990; Percival-Smith et al. 1990). In this paper we have presented a systematic mutational analysis of the $f t z \mathrm{HTH}$ motif. We have shown that the two class-specific DNA backbone-contacting amino acids, Arg-28 and Arg-43, are important determinants for the $f t z$ protein function both in vivo and in vitro. Our results support the concept that the DNA-binding affinity of the HD needs to be optimized for full function but can withstand a large amount of variation. We discuss the results in light of the available $\mathrm{HD}$ structures, assuming similar protein folds for all of the mutants.

\section{Values of different assay systems for the analysis of gene function}

Besides the implications of this study on HD function, our data allow an assessment of the values of different experimental systems for the analysis of gene function. We have tested many of the mutants in vivo for complete $f t z$ rescue potential to adult viability and for embryonic patterning activity. We have also tested them in vitro for DNA-binding activity and in cultured Drosophila cells for trans-activation activity. In general, the data obtained by these different assay systems correlate well (Figs. 1B and 6); however, several points are worthy of discussion in more detail.

1. The in vitro DNA-binding and, in particular, the cell culture systems do not allow the monitoring of some of the in vivo activities, for example, the weak embryonic patterning activity of the $f t z 5$ protein. In the presence of all of the natural set of regulatory proteins, the modular structure of transcription factors (for review, see Frankel and Kim 1991) may still allow

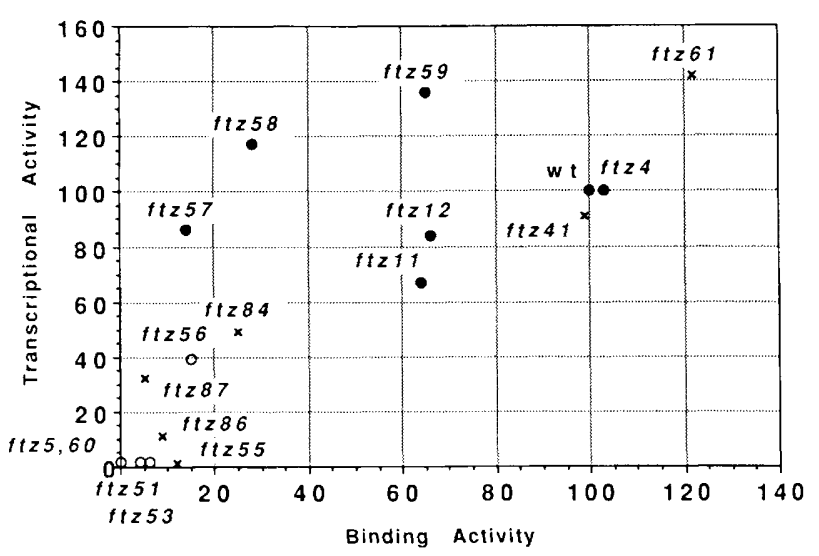

Figure 6. Comparison of $f t z$ HD mutant activities assayed by the three systems. The in vitro DNA-binding activity and the transcriptional stimulatory activity of each mutant $\mathrm{HD}$ are plotted (percent wild-type values listed in Fig. 1B). The $f t z$ rescue activity of each mutant in transgenic flies is indicated, (O) Rescue competent; $(O)$ rescue incompetent. $(x)$ Rescue activity not tested. See rescue data listed in Fig. IB and Table 1.

the $f t z 5$ protein to cooperate with other trans-acting factors and therefore to compensate to some extent for its greatly abolished activity in vitro.

2. The in vivo assay system in transgenic flies and, also to some extent, the cell culture assay system seem to be buffered against small activity changes between different mutants that can be monitored by the in vitro DNA-binding assay. For example, this assay reproducibly detected low DNA-binding activities of some of the $f t z 5$ revertants ( $t z 51, f t z 53, f t z 55$ ) that could not be distinguished from $f t z 5$ in tissue culture cells and in transgenic flies.

3. A particular set of specific amino acids improved the $f t z$ protein activity when reverted simultaneously. Comparisons of the results obtained for $f t z 5$, ftz5l, $f t z 56$, and $f t z 58$ (stepwise reversions of the three arginines at positions 28-30 and Arg-43) show that this apparent cooperative action is manifested in vivo and in cell culture systems more clearly than in the in vitro DNA-binding assay system.

4. The requirement of positions $21-24$ of the $f t z H D$ is conditional depending on the amino acid context in which they are placed and on the assay system in which they are tested. The improvement in vivo and in tissue culture cells between ftz56 and ftz57 is intriguing because it is induced without significantly changing the in vitro DNA-binding activity. The four residues are solvent exposed (Billeter et al. 1990) and could therefore be involved in association with other transcription factors.

5. As little as sixfold reduction of the in vitro DNAbinding activity from the wild-type level may lead to a severe defect of $\mathrm{ftz}$ function in flies.

In summary, our results show that the data obtained with the three different assay systems are consistent with one another and support the validities of the in 
vitro and in vivo assays for detailed mutational analyses. However, reflecting the qualitative and quantitative differences, the three assay systems are complementary to each other in monitoring the effects of various amino acid substitutions.

\section{Stability and flexibility of the $\mathrm{ftz} \mathrm{HTH}$}

Except for $f t z \Delta \mathrm{HD}$, all of our mutants retained at least some activity in vivo (see Table 1 ; Fig. 3). This fact is especially astonishing for $f t z 5$, where almost all but the highly conserved residues (Tyr-25, Arg-31, Leu-38, and Leu-40) have been exchanged between positions 21 and 45 of the $f t z$ HD. Several lines of evidence suggest that the $f t z 5$ protein is stably folded. Because most of the $f t z 5$ core-forming side chains are identical with those of the $m s h \mathrm{HD}$, the overall $f t z 5 \mathrm{HD}$ fold might be more similar to the msh HD leading to a slight change in the HD conformation (e.g., a slightly shifted alignment of the helices), which, in turn, could result in an attenuated protein-DNA interaction (Lim and Sauer 1991). However, all attempts to increase the activity of $f t z 5$ by reverting core amino acids (particularly positions 35 and 45 , which are thought to be especially important to the proper alignment of helices 2 and 3 ) failed to improve the $f t z 5$ defectiveness in vivo and in tissue culture cells, although a small increase in DNA-binding activity was observed in vitro. Instead, our results have assigned the responsible amino acids for the reduced $f t z 5$ activity to a few residues that are located on the surface of the HD. In $f t z 58$, for example, four reversions at positions $28-30$ and 43 are sufficient to restore the activity close to wild-type level in vivo. Furthermore, the results of $f t z 71-f t z 73$ clearly show that, among the three residues at the amino terminus of the HTH, only position 28 is of crucial importance. These results indicate that as a whole, the defect of $f t z 5$ may be traced back to mainly two (Arg-28 and Arg-43) of the 19 amino acid changes. The substitution of these two residues in wild-type protein $(f t z 89)$ is sufficient to abolish $\mathrm{ftz}$-dependent trans-activation in Schneider cells.

Our results also imply that a number of residues in helix 2 and the following turn can be substituted without significant loss of activity. It is interesting to note that two (ftz4) or three (ftz57, ftz58, and $f t z 59)$ of the helix 2 residues (positions 32,33 , and 36 ) that have been shown to be important to the in vitro association of Oct-1 and VP16 (Stern et al. 1989) are changed in these mutants without abolishing $f t z$-like activity in vivo.

\section{The importance of HD-DNA backbone contacts in target site recognition}

In addition to specific base-pair interactions, DNA sugarphosphate backbone contacts have been shown to play important roles in DNA recognition by prokaryotic $\mathrm{HTH}$ regulatory proteins (for review, see Harrison and Aggarwal 1990; Steitz 1990). First, they contribute to a significant part to the free energy required for the formation of a DNA-protein complex. Second, they provide crucial reference points to correctly dock the recognition helix against the major groove of the DNA (Pabo et al. 1990). Third, it has been proposed for the trp repressor-operator complex that the protein-DNA backbone contacts might be adopted to read out the DNA backbone shape that is dependent on the DNA sequence (Luisi and Sigler 1990).

Structural studies on the Antp, en, and Mat $\alpha 2$ HDDNA complexes have identified multiple DNA backbone contacts, most of which are made by the highly conserved Arg and Lys residues (Kissinger et al. 1990; Otting et al. 1990; Wolberger et al. 1991). We have shown that the highly conserved residues Tyr-25 and Arg-31 contacting the DNA backbone make important contributions to the formation of the $f t z \mathrm{HD}-\mathrm{DNA}$ complex. In addition, we have shown that the class-specific residues Arg-28 and Arg-43 are crucial to the optimum DNA binding. This is consistent with the recent highresolution NMR data on a ${ }^{13} \mathrm{C}$-labeled Antp HD-DNA complex, which have located the side chains of Arg-28 and Arg-43 in close proximity of the DNA backbone (Y.Q. Qian, G. Otting, M. Billeter, and K. Wüthrich, pers. comm.). The requirement of Arg-43 is also consistent with the methylation and ethylation interference data on the $f t z$ HD-DNA complex (Percival-Smith et al. 1990). Moreover, a DNA backbone contact at position 42 is involved in the Mat $\alpha 2$ HD-DNA complex, demonstrating that the amino terminus of the HD recognition helix is in a position to contact DNA, despite its different positioning in the major groove as compared with the prokaryotic HTH motif.

Residues 28 and 43 are less conserved within the homeo protein family (see Table 2) and could therefore contribute to a higher diversity of DNA-binding specificity among homeo proteins. Slight structural differences in the overall protein folding might result in different requirements for DNA backbone contacts in different HDDNA complexes. Alternatively, it is possible that the 2 arginines exert a more active contribution such as modification of the positioning of the recognition helix in the major groove or indirect readout of the target sequence. Although the positioning of the recognition helices is conserved between the Mat $\alpha 2$ and en HD-DNA complexes (Wolberger et al. 1991), positions 28 and 43 are substituted in the two HDs. A comparative analysis of the Antp and en HD-DNA complexes will shed more light on the importance of different sets of DNA backbone contacts established by different HDs.

\section{Materials and methods}

\section{P-element transformation vectors}

pCrfl (see Fig. 1A) was constructed by inserting the 10-kb KpnI fragment containing the $f z^{+}$gene $(f t z G$ fragment in Hiromi et al. 1985) into the KpnI site of pC20K. pC20K is a Carnegie-20 (Rubin and Spradling 1983) derivative in which the PstI site in the polylinker was replaced by a KpnI site. To mutagenize the $f t z$ homeo box, a Sall-cassette (see Fig. 1A) was subcloned into different suitable vectors. The mutants $f t z 4$ and $f t z 5$ were obtained by replacing the XmnI-BgIII fragment in the ftz homeo 
box with the homologous fragment from Scr or msh, respectively. $f t z \Delta \mathrm{HD}$ is an in-frame deletion between Glu-17 and Ile47 of the $f t z$ HD. Mutants $f t z 11, f t z 12, f t z 41$, and $f t z 51-f t z 61$ (see Fig. 1B) were obtained by site-directed mutagenesis with Amersham's oligonucleotide-directed in vitro mutagenesis system 2 . Correct clones were selected by sequencing and subsequently inserted into the transformation vector pCrf3. pCrf3 is pCrfl with the Sall cassette deleted, leaving SalI as a unique cloning site.

The three heat shock vectors pNHftz, $\mathrm{pNH} f t z 4$, and $\mathrm{pNH} f t z 5$ were constructed by inserting the pGEMfI (Krause et al. 1988)derived $f t z{ }^{+}, f t z 4$, and $f t z 5$ cDNA fragments into the unique NotI site of pNHT4 (Gibson et al. 1990). These $f t z$ heat shock vectors differ slightly from the one published in Krause et al. (1988) by a different leader sequence and by the replacement of the second amino acid (Ala) of the $f t z$-coding region by the tripeptide Arg Asp Pro.

\section{Drosophila strains and P-element-mediated transformation}

The $f t z$ alleles used in this study were $f t z^{9 H 34}, f t z^{9093}$ [ethylmethanesulfonate (EMS) induced; Jürgens et al. 1984] and $f t z^{w 20}$ (Wakimoto et al. 1984). $f t z^{\mathrm{w} 20}$ is associated with a 4.9 -kb insertion in the $f t z$ gene (Weiner et al. 1984); The molecular lesions of the other two alleles are not known. $f t z^{9093}$ homozygous embryos produce considerable amounts of the mutant protein (see Fig. 4M). ftz protein is barely detectable (Lawrence and Johntson 1989 ) in homozygous $f t z^{w 20}$ embryos. $f t z$ protein was not detectable in $\mathrm{ft}^{9 H 34}$ homozygous embryos (data not shown). Germ-line transformations were performed as described by Rubin and Spradling (1982). The recipient strain was $r y^{506}$ in all cases. Some of the transformant lines (marked $j$ in the line names in Table 1) were generated by the jump-start technique of Robertson et al. (1988). Jump-start insertions on the second chromosome were isolated on the $\mathrm{CyO}$ and $\mathrm{Sp}$ chromosomes originating from the line $\mathrm{CyO} / \mathrm{Sp} ; \mathrm{ry}^{506} / \mathrm{Sb} \mathrm{P}\left[\mathrm{ry}^{+}, \Delta 2-3\right] / T M 6$ Ubx.

\section{$\mathrm{ftz}$ rescue assay}

The ability of the mutant $f t z$ transgenes to rescue $f t z$ lethality was assayed by a similar crossing scheme as described by $\mathrm{Hi}$ romi et al. (1985), except that different marker genes were used. Adult survivors heterozygous for two $f t z$ alleles were identified by the ebony marker gene. The SI was calculated by setting the number of ebony flies in relation to the number of the phenotypically wild-type progeny of the same cross using the following equation: $\mathrm{SI}=[$ ebony $] /[+/ 2]$. The SI values shown in Table 1 represent the average of at least two independent experiments.

Cuticular preparations of embryos were made either by the protocol of Van der Meer (1977) for nondevitellinized embryos or according to Wieschaus and Nüsslein-Volhard (1986) for devitellinized embryos.

The statistical analysis of the denticle belt patterns of mutant embryos presented in Figure 3 was based on nondevitellinized preparations. A semistatistical approach was taken to analyze the different $f t z$ mutants in a $f t z^{9 H 34} / f t z^{9093}$ background. $f t z$ embryos have only four abdominal denticle belts owing to segmental fusions and deletions (Wakimoto and Kaufman 1981). Most of the $\mathrm{ftz}$ mutants analyzed in this study retain at least some activity leading to an embryonic rescue phenotype, which manifests itself in partial or complete formation of denticle belts that are missing in $f t z$ embryos. Reformation of denticle belts in the abdominal segments, A1, A3, A5, and A7, was scored individually in the following way: (1) no denticle hairs $=0 ;(2)$ partially formed denticle belt $=0.5$; and $(3)$ com- pletely restored denticle belt $=1$. The scores for each of the four segments were added up and divided by the number of embryos showing an embryonic rescue phenotype.

\section{Immunostaining of embryos}

Antibody staining was performed essentially as described in LeMotte et al. (1989). The $\mathrm{ftz}$ antiserum was a rabbit polyclonal serum used at a dilution of $1: 200$ (Krause et al. 1988). The mouse monoclonal en antiserum (Patel et al. 1989) was used at a dilution of $1: 100$.

\section{Heat shock experiments}

Experiments were done as described (Struhl 1985), with minor modifications. Dechorionated embryos were placed on a wet blotting paper in a plastic petri dish. The dish was sealed and immersed into a water bath at $37^{\circ} \mathrm{C}$ for $20 \mathrm{~min}$. The embryos were then allowed to develop at $25^{\circ} \mathrm{C}$ for $24 \mathrm{hr}$ on fresh grape juice plates before they were mounted in Hoyer's medium as described above.

\section{Plasmids for cell culture experiments}

The $f t z$ producer plasmid pAcftz was constructed by inserting a 1.8-kb genomic fragment into the BamHI site of pPac (Krasnow et al. 1989). In addition to the entire coding sequence of $f t z$, this insert has a 20-bp leader, 150-bp intron, and 420-bp trailer of $\mathrm{ftz}$ genomic DNA. The mutant DNAs constructed for the fly experiments were used for pAcftz4, ftz 41 , and $f t z 51-f t z 61$. The XhoI-BgIII fragment of pAcftz was substituted by the mutant fragments. Mutants $f t z 1-f t z 77$ were constructed by inserting the corresponding mutant oligonucleotide directly between the $X$ hoI and EcoRI sites (amino acids 16-34) of ftz59. The EcoRI site was incidentally created during mutant construction without changing the encoded amino acid. $f t z 79$ was constructed in the same way except that a mutant oligonucleotide cassette between the EcoRI and BgIII sites (amino acids 33-48) was used. Mutants $f t z 81-f t z 88$ were constructed by inserting the corresponding mutant oligonucleotide cassette between the XhoI and EcoRV (amino acids 16-34) sites of pAcftz wild-type. Mutant clones were identified by directly sequencing the ampicilin-resistant clones. The list of oligonucleotides used for mutagenesis is available upon request. The reporter gene pF11CAT was constructed by subcloning oligomerized BS2-26 (AGCTGAGAAAAAGCCATTAGAGAAGC; Müller et al. 1988) oligonucleotides and the $h s p 70$ basic promoter (spanning -50 to +90 ) into the unique PstI site of pC4CAT (Thummel et al. 1988).

\section{Transfection assay with Drosophila tissue culture cells}

Schneider line 1 (S1W220) cells were used for transfection experiments. S1W220 cells showed higher transfection efficiency than Schneider line 2 cells. Cells were grown at $25^{\circ} \mathrm{C}$ in Schneider medium containing $15 \%$ fetal bovine serum (heat inactivated, GIBCO). DNA transfection was done with calcium phosphate as described (Rio and Rubin 1985). Each transfection contained $3 \mu \mathrm{g}$ of producer, $1 \mu \mathrm{g}$ of reporter, and $6 \mu \mathrm{g}$ of pcopßgal DNAs per plate. pcop $\beta$ gal expresses the $\beta$-galactosidase gene under copia long terminal repeat (LTR) and served as an internal control. The expression of pcopßgal was not affected by the cotransfection of the $f t z$ producer construct. After $42-48 \mathrm{hr}$, cells were harvested and extracts were prepared by freezing and thawing. All transfections were done in duplicate plates. CAT activities were determined by the fluor-diffusion method with 
${ }^{3} \mathrm{H}$-labeled acetyl CoA as described by the distributor (New England Nuclear). $\beta$-Galactosidase activities were determined with chlorophenol red- $\beta$-D-galactopyranoside (Boehringer Mannheim). CAT activity was normalized against the control $\beta$-gal activity. Transfection assays were repeated at least three times, and the values were averaged.

\section{Determination of DNA binding activities with in vitro-synthesized proteins}

DNA-binding activities of in vitro-synthesized proteins were determined as described by Hope and Struhl (1985). A 60-bp BamHI fragment containing BS2-binding site (F1-60: GATCCCCGCG GCCGCTT CTC TAATGGCTTT TTCTCAGCTG GCCGCGGGTA CCGGGGGATC; nucleotides corresponding to BS2-18 are underlined) was used as a probe. The synthesized protein was analyzed by separation through SDS-polyacrylamide gels, and the amounts of protein were estimated by TCA precipitation assay for $\left[{ }^{35} \mathrm{~S} \mid\right.$ methionine according to the method of the supplier of the lysates (Promega). DNA-binding reactions were done at room temperature for $20 \mathrm{~min}$ in $20 \mathrm{mM}$ HEPES / $\mathrm{pH}$ 7.9), 4\% Ficoll 400, $50 \mathrm{~mm} \mathrm{KCl,} 1 \mathrm{~mm}$ EDTA, $1 \mathrm{~mm}$ DTT, 0.25 $\mu \mathrm{g} / \mathrm{ml}$ of BSA, and $50 \mu \mathrm{g} / \mathrm{ml}$ of [poly|I-C)]. The protein-DNA complexes were resolved through $8 \%$ polyacrylamide gels in $0.25 \times$ TBE buffer at room temperature. The bound and unbound fractions of the probe DNA were determined by laser computing densitometry with films of different exposure times.

\section{$\mathrm{K}_{d}$ measurements with $H D$ peptides synthesized in $\mathrm{E}$. coli}

$f t z$ HD peptides (73 amino acids) were purified from E. coli as described for the Antp HD (Müller et al. 1988) except that the protein was induced at $18^{\circ} \mathrm{C}$ after growing up the cultures at $37^{\circ} \mathrm{C}$ to $\mathrm{OD}_{600}=1.0$. The peptide expressed from the $\mathrm{T} 7 \mathrm{ex}-$ pression vector (Studier and Moffatt 1986), pfopl, is identical to the one used in Percival-Smith et al. (1990). Mutant versions of pfopl used in this study were pfop11, pfop12, pfop4, pfop41, pfop59, pfop84, pfop86, and pfop87. The numbers of these plasmids correspond to the mutant numbers in Figure 1B. Binding reactions for the saturation experiments were carried out as described by Affolter et al. (1990), with BS2-18 (GAGAAAAAGCCATTAGAG) as a probe.

\section{Acknowledgments}

We thank Yan Qiu Qian, Gottfried Otting, Martin Billeter, and Kurt Wüthrich for sharing the structure information on the Antp HD-DNA complex before publication; Paul Baumgartner for Southern blot analyses of genomic DNAs; Hugo Bellen, Anthony Percival-Smith, and Alex Schier for discussions; and Ursula Weber for performing some of the initial P-element-mediated transformations. We thank Yash Hiromi for plasmids and advice to M.M. at early stages of this work, Beat Suter for help during the preparation of Figure 1, Henry Krause for $f t z$ antibody, and Nipam Patel and Corey Goodman for en antibody. pPAc and pC4CAT were kindly provided by Wolfgang Driever. We thank Alex Schier for critical reading of the manuscript, Maria Rizzieri for preparation of Schneider medium, and Erika Wenger-Marquardt for her help in typing. L.P. was supported by a Damon Runyon-Walter Cancer Fund Fellowship (DRG-912). K.F.-T. was supported partly by Mochida Foundation Japan for his travel expenses to Basel. This work was supported by grants from the Swiss National Science Foundation and the Kantons Basel-Stadt and Basel-Landschaft.
The publication costs of this article were defrayed in part by payment of page charges. This article must therefore be hereby marked "advertisement" in accordance with 18 USC section 1734 solely to indicate this fact.

\section{References}

Affolter, M., A. Percival-Smith, M. Müller, W. Leupin, and W.J. Gehring. 1990. DNA binding properties of the purified Antennapedia homeo domain. Proc. Natl. Acad. Sci. 87: 40934097.

Billeter, M., Y.-Q. Qian, G. Otting, M. Müller, W.J. Gehring, and K. Wüthrich.1990. Determination of the three-dimensional structure of the Antennapedia homeo domain from Drosophila in solution by $1 \mathrm{H}$ nuclear magnetic resonance spectroscopy. J. Mol. Biol. 214: 183-197.

Carroll, S.B. and M.P. Scott 1985. Localization of the fushi tarazu protein during Drosophila embryogenesis. Cell 43: 47-57.

Desplan, C., J. Theis, and P.H. O'Farrell. 1988. The sequence specificity of homeo domain-DNA interaction. Cell 54: 1081-1090.

DiNardo, S. and P.H. O'Farrell. 1987. Establishment and refinement of segmental pattern in the Drosophila embryo: Spatial control of engrailed expression by pair-rule genes. Genes \& Dev. 1: 1212-1225.

DiNardo, S., J.M. Kuner, J. Theis, and P.H. O'Farrell. 1985. Development of embryonic pattern in $D$. melanogaster as revealed by accumulation of the nuclear engrailed protein. Cell 43: 59-69.

DiNardo, S., E. Sher, J. Heemskerk-Jongens, J.A. Kassis, and P.H. O'Farrell. 1988. Two-tiered regulation of spatially patterned engrailed gene expression during Drosophila embryogenesis. Nature 332: 604-609.

Edgar B.A., G.M. Odell, and G. Schubiger. 1987. Cytoarchitecture and the patterning of fushi tarazu expression in the Drosophila blastoderm. Genes \& Dev. 1: 1226-1237.

Fjose, A., W.J. McGinnis, and W.J. Gehring. 1985. Isolation of the homeo box-containing gene from the engrailed region of Drosophila and the spatial distribution of its transcripts. $\mathrm{Na}$ ture 313: 284-289.

Frankel, A.D. and P.S. Kim. 1991. Modular structure of transcription factors: Implications for gene transcription. Cell 65: 717-719.

Frasch, M., R. Warrior, J. Tugwood, and M. Levine. 1988. Molecular analysis of even-skipped mutants in Drosophila development. Genes \& Dev. 2: 1824-1838.

Gehring, W.J., M. Müller, M. Affolter, A. Percival-Smith, M. Billeter, Y.-Q. Qian, G. Otting, and K. Wüthrich. 1990. The structure of the homeo domain and its functional implications. Trends Genet. 6: 323-329.

Gibson, G., A. Schier, P. LeMotte, and W.J. Gehring. 1990. The specificities of Sex comb reduced and Antennapedia are defined by a distinct portion of each protein that includes the homeo domain. Cell 62: 1087-1103.

Han, K., M.S. Levine, and J.L. Manley. 1989. Synergistic activation and repression of transcription by Drosophila homeo box proteins. Cell 56: 573-583.

Hanes, S.D. and R. Brent. 1989. DNA specificity of the bicoid activator protein is determined by homeo domain recognition helix residue 9. Cell 57: 1275-1283.

Harrison, S.C. and A.K. Aggarwal. 1990. DNA recognition by proteins with the helix-turn-helix motif. Annu. Rev. Biochem. 59: 933-969.

Hayashi, S. and M.P. Scott. 1990. What determines the speci- 
ficity of action of Drosophila homeo domain proteins? Cell 63: $883-894$.

Hiromi, Y. and W.J. Gehring. 1987. Regulation and function of the Drosophila segmentation gene fushi tarazu. Cell 50: $963-974$.

Hiromi, Y., A. Kuroiwa, and W.J. Gehring. 1985. Control elements of the Drosophila segmentation gene fushi tarazu. Cell 43: 603-613.

Hochschild, A., N. Irwin, and M. Ptashne. 1983. Repressor structure and the mechanism of positive control. Cell 32: 319-325.

Hoey, T. and M. Levine. 1988. Divergent homeo box proteins recognize similar DNA sequences in Drosophila. Nature 332: $858-861$.

Hope, I.A. and K. Struhl. 1985. GCN4 protein, synthesized in vitro, bind HIS3 regulatory sequences. Implication for general control of amino acid biosynthetic genes in yeast. Cell 43: $177-188$.

Howard, K. 1990. The blastoderm prepattern. Sem Cell Biol. 1: $161-172$.

Ish-Horowicz, D. S.M. Pinchin, P.W. Ingham, and H. Gyurkovisc. 1989. Autocatalytic $f t z$ activation and metameric instability by ectopic $f t z$ expression. Cell 57: 223-232.

Jaynes, J.B. and P.H. O'Farrell. 1988. Activation and repression of transcription by homeo domain-containing proteins that bind a common site. Nature 336: 744-749.

Jürgens, G., E. Wieschaus, C. Nüsslein-Volhard, and H. Kluding. 1984. Mutations affecting the pattern of the larval cuticle in Drosophila melanogaster. Wilhelm Roux's Arch. Dev. Biol. 193: 283-295.

Kellerman, K.A., D.M. Mattson, and I. Duncan. 1990. Mutations affecting the stability of the fushi tarazu protein of Drosophila. Genes \& Dev. 4: 1936-1950.

Kissinger, C.R., B. Liu, E. Martin-Blanco, T.B. Kornberg, and C.O. Pabo. 1990. Crystal structure of an engrailed homeo domain-DNA complex at $2.8 \AA$ resolution: A framework for understanding homeo domain-DNA interactions. Cell 63: $579-590$.

Kornberg, T. 1981. engrailed: A gene controlling compartmet and segment formation in Drosophila. Proc. Natl. Acad. Sci. 78: 1095-1099.

Krasnow, M.A., E.E. Saffman, T. Kornfeld, and D.S. Hogness. 1989. Transcriptional activation and repression by Ultrabithorax proteins in cultured Drosophila cells. Cell 57: 1031-1043.

Krause, H.M., R. Klemenz, and W.J. Gehring. 1988. Expression, modification, and localization of the fushi tarazu protein in Drosophila embryos. Genes \& Dev. 2: 1021-1036.

Kuziora, M.A. and W. McGinnis. 1989. A homeo domain substitution changes the regulatory specificity of the Deformed protein in Drosophila embryos. Cell 59: 563-571.

Laughon, A. and M.P. Scott. 1984. Sequence of a Drosophila segmentation gene: Protein structure homology with DNAbinding proteins. Nature 310: 25-31.

Lawrence, P.A. and P. Johnston. 1989. Pattern formation in the Drosophila embryo: Allocation of cells to parasegments by even-skipped and fushi tarazu. Development 105: 761-767.

LeMotte, P.K., A. Kuroiwa, L.I. Fessler, and W. Gehring. 1989. The homeotic gene Sex combs reduced of Drosophila: Gene structure and embryonic expression. EMBO I. 8: 219-227.

Lim, W.A. and R.T. Sauer. 1991. The role of internal packing interactions in determining the structure and stability of a protein. I. Mol. Biol. 219: 359-376.

Luisi, B.F. and P.B. Sigler. 1990. The stereochemistry and biochemistry of the trp repressor-operator complex. Biochim. Biophys. Acta 1048: 113-126.
Mann, R.S. and D.S. Hogness. 1990. Functional dissection of Ultrabithorax proteins in D. melanogaster. Cell 60: 597610.

Müller, M., M. Affolter, W. Leupin, G. Otting, K. Wüthrich, and W.J. Gehring. 1988. Isolation and sequence-specific DNA binding of the Antennapedia homeo domain. EMBO J. 7: 4299-4304.

Otting, G., Y.Q. Qian, M. Billeter, M. Müller, M. Affolter, W.J. Gehring, and K. Wüthrich. 1990. Protein-DNA contacts in the structure of a homeo domain-DNA complex determined by nuclear magnetic resonance-spectroscopy in solution. EMBO J. 9: 3085-3092.

Pabo, C.O., A.K. Aggarwal, S.R. Jordan, L.J. Beamer, U.R. Obeysekare, and S.C. Harrison. 1990. Conserved residues make similar contacts in two repressor-operator complexes. Science 247: 1210-1213.

Pakula, A.A. and R.T. Sauer. 1989. Genetic analysis of protein stability and function. Annu. Rev. Genet. 23: 289-310.

Patel, N.H., E. Martin-Blanco, K.G. Coleman, S.J. Poole, M.C. Ellis, T.B. Kornberg, and C.S. Goodman. 1989. Expression of engrailed proteins in arthropods, annelids, and chordates. Cell 58: 955-968.

Percival-Smith, A., M. Müller, M. Affolter, and W. Gehring. 1990. The interaction with DNA of wild-type and mutant fushi tarazu homeo domains. EMBO J. 9: 3967-3974.

Pick, L., A. Schier, M. Affolter, T. Schmidt-Glenewinkel, and W.J. Gehring. 1990. Analysis of the $f t z$ upstream element: Germ layer-specific enhancers are independently autoregulated. Genes \& Dev. 4: 1224-1239.

Qian, Y.Q., M. Billeter, G. Otting, M. Müller, W.J. Gehring, and K. Wüthrich. 1989. The structure of the Antennapedia homeo domain determined by NMR spectroscopy in solution: Comparison with prokaryotic repressors. Cell 59: 573-580.

Rio, D.C. and G.M. Rubin. 1985. Transformation of cultured Drosophila melanogaster cells with a dominant selectable marker. Mol. Cell. Biol. 5: 1833-1838.

Robert, B., D. Sassoon, B. Jacq, W. Gehring, and M. Buckingham. 1989. Hox-7, a mouse homeo box gene with a novel pattern of expression during embryogenesis. EMBO I. 8: 91-100.

Robertson, H.M., C. Preston, R. Phillips, D. Johnson-Schilz, W. Benz, and W. Engels. 1988. A stable genomic source of P-element transposase in Drosophila melanogaster. Genetics 118: 461-470.

Ruberti, I., G. Sessa, S. Lucchetti, and G. Morelli. 1991. A novel class of plant proteins containing a homeo domain with a closely linked leucine zipper motif. EMBO I. 10: 1787-1791.

Rubin, G.M. and A.C. Spradling. 1982. Genetic transformation of Drosophila with transposable element vectors. Science 218: 348-353.

_- 1983. Vectors for P element-mediated gene transfer in Drosophila. Nucleic Acids Res. 11: 6341-6351.

Sauer, R.T., S.R. Jordan, and C.O. Pabo. 1990. $\lambda$ repressor: A model system for understanding protein-DNA interactions and protein stability. Adv. Protein Chem. 40: 1-61.

Schier A.F. and W.J. Gehring. 1992. Direct homeo domain-DNA interaction in the autoregulation of the fushi tarazu gene. Nature (in press).

Scott, M.P., J.W. Tamkun, and G.W. Hartzell III. 1989. The structure and function of the homeo domain. Biochim. Biophys. Acta 989: 25-48.

Shepherd, J.C., W. McGinnis, A.E. Carrasco, R.M. DeRobertis, and W.J. Gehring. 1984. Fly and frog homeo domains show homologies with yeast mating type regulatory proteins. $\mathrm{Na}$ ture 310: 70-71.

Steitz, T.A. 1990. Structural studies of protein-nucleic acid interaction: The sources of sequence-specific binding. $Q$. Rev. 


\section{Furukubo-Tokunaga et al.}

Biophys. 23: 205-280.

Stern, S., M. Tanaka, and W. Herr. 1989. The Oct-1 homeo domain directs formation of a multiprotein-DNA complex with the HSV transactivator VP16. Nature 341: 624-630.

Studier, F.W. and B.A. Moffatt. 1986. Use of bacteriophage T7 RNA polymerase to direct selective high-level expression of cloned genes. I. Mol. Biol. 189: 113-130.

Struhl, G. 1985. Near reciprocal phenotypes caused by inactivation or indiscriminate expression of the Drosophila segmentation gene $f t z$. Nature 318: 677-680.

Thummel, C.S., A.M. Boulet, and H.D. Lipshitz. 1988. Vectors for Drosophila P-element-mediated transformation and tissue culture transfection. Gene 74: 445-456.

Treisman, J., P. Gönczy, M. Vashishtha, E. Harris, and C. Desplan. 1989. A single amino acid can determine the DNA binding specificity of homeo domain proteins. Cell 59: 553562.

Van der Meer, J.M. 1977. Optical clean and permanent wholemount preparations for phase contrast microscopy of cuticular structures of insect larvae. Dros. Inf. Serv. 52: 160.

Wakimoto, B. and T.C. Kaufman. 1981. Analysis of larval segmentation in lethal genotypes associated with the Antennapedia gene complex in Drosophila melanogaster. Dev. Biol. 81: $51-64$.

Wakimoto, B.T., F.R. Turner, and T.C. Kaufman. 1984. Defects in embryogenesis in mutants associated with the Antennapedia gene complex of Drosophila melanogaster. Dev. Biol. 102: $147-172$.

Weiner, A.J., M.P. Scott, and T.C. Kaufman. 1984. A molecular analysis of fushi tarazu, a gene in Drosophila melanogaster that encodes a product affecting embryonic segment number and cell fate. Cell 37: 843-851.

Wieschaus, E. and C. Nüsslein-Volhard. 1986. Looking at embryos. In Drosophila, a practical approach. (ed. D.B. Roberts|, pp. 199-227. IRL Press, Oxford, England.

Winslow, G. M., S. Hayashi, M.A. Krasnow, D.S. Hogness, and M.P. Scott. 1989. Transcriptional activation by the Antennapedia and fushi tarazu proteins in cultured Drosophila cells. Cell 57: 1017-1030.

Wolberger, C., A.K. Vershon, B. Liu, A.D. Johnson, and C.O. Pabo. 1991. Crystal structure of a MAT $\alpha 2$ homeo domainoperator complex suggests a general model for homeo domain-DNA interactions. Cell 67: 517-528. 


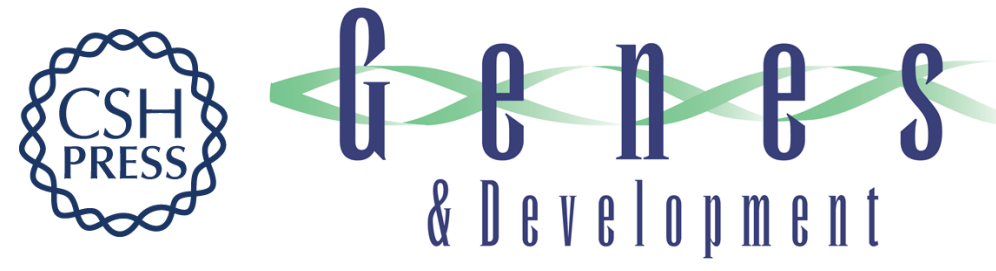

\section{In vivo analysis of the helix-turn-helix motif of the fushi tarazu homeo domain of Drosophila melanogaster.}

K Furukubo-Tokunaga, M Müller, M Affolter, et al.

Genes Dev. 1992, 6:

Access the most recent version at doi:10.1101/gad.6.6.1082

References This article cites 67 articles, 13 of which can be accessed free at: http://genesdev.cshlp.org/content/6/6/1082.full.html\#ref-list-1

License

Email Alerting

Service

Receive free email alerts when new articles cite this article - sign up in the box at the top right corner of the article or click here.

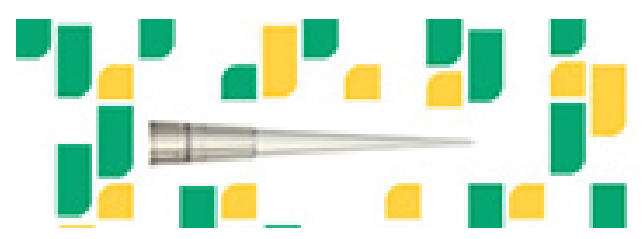

Focused on your science. 